\title{
CNC Torna Tezgâhlarında Ayna ve Punta Basıncının Yüzey Pürüzlülüğü ve Titreşim Üzerine Etkisinin Taguchi Metodu İle Optimizasyonu
}

\author{
Geliş / Received: 20/09/2019
}

\author{
Hüseyin GÜRBÜZ ${ }^{*}$, Şehmus BADAY ${ }^{2}$
}

ÖZ

\begin{abstract}
Tornalama işlemlerinde, istenmeyen yüksek değerlerdeki yüzey pürüzlülük ve titreşim değerlerini gidermek için iş parçaları tezgâha doğru bir şekilde bağlanması gerekmektedir. Bir iş parçası; uygun bir basınç ile ayna ve punta arasına bağlanmadığında, bu, onun eksenden kaçık salgılı bir şekilde dönmesine ve ölçü tamlığının bozulmasına yol açmaktadır. Bunun sonucunda, iş parçasında istenmeyen, yüksek değerlerde yüzey pürüzlülük ve titreşim değerleri meydana gelir. Bu çalışmanın amacı, Taguchi metodunu kullanarak AISI 304 paslanmaz çeliğinin tornalanmasında en düşük yüzey pürüzlülüğü ve titreşim değerlerini elde etmek için en uygun ayna ve punta basıncını tespit etmektir. İşleme deneylerinde, sabit kesme hızı, ilerleme ve kesme derinliğinde 5 farklı ayna ve punta basıncı kullanılmıștır. Deney tasarımı için Taguchi $\mathrm{L}_{25}\left(5^{\wedge} 2\right)$ ortogonal dizilimi seçilmiștir. En küçük en iyidir yaklaşımına göre $\mathrm{S} / \mathrm{N}$ (sinyal/gürülttü) oranı kullanılarak yüzey pürüzlülügüü ve titreşim değerleri için en uygun ayna ve punta basıncı belirlenmiştir. $\mathrm{S} / \mathrm{N}$ oranlarına göre optimum ve en düşük titreşim değerlerini veren ayna ve punta basıncı sırasıyla 18 bar ve 5 bar iken, optimum yüzey pürüzlülük değerlerini veren ayna ve punta basıncı değerleri ise sırasıyla 18 bar ve 11 bar olarak tespit edilmiştir. Fakat en düşük yüzey pürüzlülük değeri ise ayna basıncı 18 bar ve punta basınc 5 barda elde edilmiştir. Taguchi deney tasarımındaki $\mathrm{S} / \mathrm{N}$ oranı sonuçlarına göre, yüzey pürüzlülüğü ve titreşim üzerinde ayna basıncının punta basıncından daha etkili olduğu ortaya çıkmıştır. Sonuç olarak; ayna ve punta basıncı parametrelerinin optimizasyonu için Taguchi yöntemindeki faktör tasarımının; basit, sistematik ve verimli bir yöntem olduğu anlaşılmıştır.
\end{abstract}




\title{
Optimization of Effect of Chuck and Tailstock Pressure on Surface Roughness and Vibration with Taguchi Method in CNC Lathes
}

\begin{abstract}
In turning operations, the workpieces must be correctly attached to the workbench to eliminate undesirable high values of surface roughness and vibration. When a workpiece is not attached with an appropriate pressure between chuck and tailstock, this will cause it to rotate eccentrically out-of-axis and deterioration of dimensional accuracy. As a result of this, undesirable high surface roughness values and vibrations in the workpiece occur. The aim of this study is to determine the optimum chuck and tailstock pressure using Taguchi method in order to obtain the lowest surface roughness and vibration values in turning of AISI 304 stainless steel. In the machining experiments, at constant cutting speed, feed and depth of cut, 5 different chuck and tailstock pressures, were used. For the experimental design, Taguchi $\mathrm{L}_{25}\left(5^{\wedge} 2\right)$ orthogonal array was chosen. According to the-smaller-thebetter approach, optimum chuck and tailstock pressures were determined for surface roughness and vibration values using $\mathrm{S} / \mathrm{N}$ (signal/noise) ratio. According to $\mathrm{S} / \mathrm{N}$ ratios, the optimum and lowest vibration values were determined as 18 bar and 5 bar, respectively, while the optimum surface roughness values were determined as 18 bar and 11 bar, respectively. However, the lowest surface roughness value was obtained when the chuck pressure was 18 bar and tailstock pressure was 5 bar. According to the results of the $\mathrm{S} / \mathrm{N}$ ratio in Taguchi test design, it was revealed that the chuck pressure on surface roughness and vibration was more effective than the tailstock pressure. In conclusion, it was understood that factor design in Taguchi method is a simple, systematic and efficient method for optimization of chuck and tailstock pressure parameters.
\end{abstract}




\section{I.GIRIŞ}

İmalat sektöründe gereksinim duyulan ihtiyaçların en başında, düşük yüzey pürüzlülük değerlerinde üretilen iş parçaları yer almaktadır. Talaş kaldırma işleminin amacı, sadece iş parçalarına şekil vermek değil aynı zamanda geometri, boyut bakımından da belirli bir tolerans ve doğruluk derecesine göre ideal bir yüzey kalitesinde imal etmektir [1]. Bir iş parçasının yüzey kalitesinin yüksek olması daha uzun ömürlü çalışmasına katkı sağlayarak iş parçası imalatına ayrılmış olan üretim maliyetlerinin azaltmasına yardımcı olacaktır. Aynı zamanda kaliteli işlenmiş bir yüzey, yorulma ömrünü, korozyon ve aşınma direncini önemli derecede iyileştirecektir. Fakat işleme şartları veya imalat sürecindeki diğer problemlerden kaynaklanan yüzey düzensizlikleri, istenmeyen yüzey pürüzlülüklerine sebep olmaktadır. Bu problemlerden biride titreşim (tırlama) olayıdır. Titreşim olayı, kesici takım iş parçasını işlerken oluşan anlık değişimlerden dolayı oluşur [2]. İş parçaları işlenirken istenmeyen yüksek yüzey pürüzlülük değerlerinin ve titreşimlerin giderilmesinin ilk adımı iş parçalarının doğru bir şekilde tezgâha bağlanmasıyla sağlanmaktadır. Bir iş parçasının ideal punta ve ayna basıncında bağlanması, iş parçası işlenirken oluşacak salgıları, esnemeyi ve titreşim olayını azaltarak iş parçalarından istenen ideal yüzey kalitesinin elde edilmesine yardımcı olacaktır.

Son yıllarda, çeşitli malzemelerin tornalanması sonucu meydana gelen yüzey pürüzlülüğü ve titreşim üzerinde kesme parametrelerinin etkilerini belirlemek için deney tasarım metotlarına ve analizlerine dayanan çeşitli istatistiksel ve deneysel çalışmalar yapılmıştır [3-19]. Fakat ayna ve punta basıncının titreşim ve yüzey pürüzlülüğü üzerindeki etkisini belirlemek için optimizasyon yapan her hangi bir deneysel ve istatiksel çalışma yapılmamıştır. Günay ve Yücel iki farklı sertliğe sahip yüksek alaşımlı beyaz dökme demirin tornalanmasında optimum yüzey pürüzlülüğünü belirlemek için Taguchi $\mathrm{L}_{18}$ ortogonal dizilimi kullanmışlardır. En uygun kesme koşullarını, en küçük en iyidir 'yaklaşımına göre hesaplanan $\mathrm{S} / \mathrm{N}$ (sinyal-gürültü) oranı kullanılarak belirlemişlerdir. $62 \mathrm{HRc}$ sertliğe sahip iş parçası yüzeyinden elde edilen yüzey pürüzlülük değerleri üzerinde ilerlemenin etkili olduğunu, $50 \mathrm{HRc}$ sertliğe sahip iş parçası yüzeyinden elde edilen yüzey pürüzlülük değerleri üzerinde ise kesme hızının etkili olduğunu bulmuşlardır [3]. Rao ve Venkatasubbaiah Taguchi'nin L9 ortogonal dizilimi ve ANOVA (varyans analizi) kullanılarak kesme parametrelerinin AA7075 çelik iş parçasının tornalanması sonucu oluşan yüzey pürüzlülüğü üzerindeki etkisini araştırmışlardır. Taguchi sonuçlarından ilerleme ve kesme hızının, yüzey pürüzlülüğünü etkileyen en önemli parametreler olduğunu ve düşük yüzey pürüzlülüğü için kesme parametrelerinin optimal kombinasyonun kesme hızı $1000 \mathrm{~m} / \mathrm{dak}$, ilerleme $0,2 \mathrm{~mm} / \mathrm{dev}$ ve kesme derinliği 0,5 mm'de olduğunu bulmuşlardır [4]. Salvi ve ark. taguchi metodu kullanarak sert tornalama sonucu oluşan yüzey pürüzlülüğü değerlerinin analizini yapmışlardır. Yazarlar elde etmiş oldukları sonuçlarla, düşük yüzey pürüzlülüğü elde etmede ilerlemenin ve ardından kesme hızının önemli bir rol oynadığını göstermişlerdir [5]. Debnath ve ark. Taguchi yöntemi kullanarak tornalama işleminde yüzey pürüzlülüğü ve takım aşınması üzerinde kesme sıvısı koşullarının ve kesme parametrelerinin etkisini araştırmışlardır. İstenilen yüzey pürüzlülüğ̈̈ ve takım aşınması için optimum kesme koşulları için yüksek kesme hızı, orta kesme derinliği, düşük ilerleme ve düşük akışlı yüksek hızlı kesme sıvısı olduğunu tespit etmişlerdir [6]. Nalbant ve ark. çalışmalarında, AISI 1030 çeliğinin tornalanması sonucu oluşan yüzey pürüzlülüğü üzerinde optimum kesme parametrelerini etkisini belirlemek için taguchi metodu kullanarak ortogonal dizilim, $\mathrm{S} / \mathrm{N}$ oranı ve ANOVA uygulamışlardır. Elde etmiş oldukları sonuçlar ışığında yüzey pürüzlülüğü üzerinde en önemli etkiye sırasıyla kesici takım burun radyüsü, ilerleme ve kesme derinliği olduğunu bulmuşlardır [7]. Çetin ve ark. AISI 304L çeliğinin tornalanması sırasında kesme kuvveti ve yüzey pürüzlülüğü üzerinde kesme parametrelerinin etkisini görmek için regresyon, $S / N$ ornı ve ANOVA analizi yapmışlardır. Yazarlar, yüzey pürüzlülüğü $\left(R^{2}>0,98\right)$ ve kesme kuvveti $\left(R^{2}>0,97\right)$ için elde etmiş oldukları regresyon modellerinin değerleri ile deneysel değerlerin birbirleriyle iyi uyumlu olduğunu tespit etmişlerdir. Ayrıca yüzey pürüzlülüğünü iyileștirmede ve kesme kuvvetlerini düşürmede ilerleme ve kesme derinliğinin kesme hızından ve kesme sıvılarından daha etkili olduğunu bulmuşlardır [8]. Bagaber ve Yusoff, ANOVA kullanarak AISI 316 paslanmaz çeliğinin kuru tornalanmasında güç tüketimini minimize etmek için kesme parametrelerini optimize etmişlerdir. Çalışmalarında, güç tüketiminin minumum değerlerini en düşük kesme hızında, en yüksek ilerleme ve kesme derinliğinde elde ettiklerini vurgulamışlardır. Yüzey pürüzlülüğü üzerinde en etkili parametrelerin ilerleme ve daha sonra kesme hızının olduğunu bulmuşlardır [9]. Benzer bir çalışmada Bhattacharya ve ark. AISI 1045 çeliğinin yüksek hızda işlenmesi sırasında kesme parametrelerinin yüzey pürüzlülüğü ve güç tüketimi üzerindeki etkisinin tahmin etmek için Taguchi metodu ve ANOVA uygulamışlardır. Elde etmiş oldukları sonuçlardan kesme hızının yüzey pürüzlülüğü ve güç tüketimi üzerinde önemli bir etkiye sahip olduğunu diğer kesme parametrelerin ise çok az bir etkisinin olduğunu bulmuşlardır [10]. Daha sonraki yıllarda Camposeco-Negrete, 
Taguchi metodu ve ANOVA kullanarak AISI 6061 T6 alüminyum iş parçasının tornalanmasında yüzey pürüzlülüğü ve güç tüketimini en aza indirmek için kesme parametrelerin optimizasyonu yapmıştır. Yazar, tüketilen enerjiyi en aza indirmek için en önemli faktörlerin sırasıyla ilerleme, kesme derinliği ve kesme hızı olduğunu ve yüzey pürüzlülüğü değerlerini en aza indirmek için ise en önemli parametrenin ilerleme olduğunu bulmuştur [11]. Yaka ve ark. AISI 1040 çeliğinin tornalama işleminde kesme parametrelerinin yüzey pürüzlülüğü üzerinde etkisini araştırmak için Taguchi $\mathrm{L}_{9}$ ortogonal dizilimi kullanılarak kesme parametrelerinin optimizasyonu yapmışlardır. ANOVA analizinde ilerlemenin Ra değerinde \%95 güven düzeyinde etki ettiğini ve Taguchi tahmininde seçilen parametreler için yapılan tekrar deneyinde Taguchi'nin \%89 güvenilirlik ile sonuç verdiği tespit etmişlerdir [12]. Akkuş AISI 4140 çeliğin tornalanması sonucu oluşan yüzey pürüzlülüğü değerleri için optimum kesme parametrelerini belirlemek üzere Taguchi L9 ortogonal dizilim kullanarak bir çalışma gerçekleştirmiştir. Yazar, yüzey pürüzlülüğü üzerinde en etkili parametrenin kesme derinliği olduğunu tespit etmiştir. ANOVA'da sırasıyla kesme derinliğinin, kesme hızının, ilerlemenin ve soğutma sıvısının Ra değerine \% 95 güvenirliğinde etkilediğini tespit etmiştir [13]. Yılmaz ve ark. INCONEL 718 iş parçasının yüzey pürüzlülük değerlerini tahmin etmek için Taguchi $\mathrm{L}_{16}$ deney tasarımını kullanmışlardır. Yaptıkları ANOVA sonucunda yüzey pürüzlülüğü üzerinde en önemli etkiye sahip parametrelerin sırasıyla kesme derinliği, kesme hızı ve daha sonra ilerlemenin olduğunu bulmuşlardır [14]. Asiltürk ve Akkuş Taguchi metodu kullanarak AISI 4140 çeliğinin sert tornalanmasında yüzey pürüzlülüğü üzerinde kesme parametrelerin etkisini belirlemişlerdir. Yazarlar, hangi kesme parametrelerinin istatistiksel olarak anlamlı olduğunu görmek için ANOVA kullanmışlardır. Yaptıkları çalışmanın sonucunda ilerlemenin yüzey pürüzlülüğü üzerinde en önemli etkiye sahip olduğunu tespit etmişlerdir [15]. Selvaraj ve ark. iki farklı paslanmaz çeliğin kuru tornalanmasında yüzey pürüzlülüğ̈̈ üzerinde kesme parametrelerin etkisini görmek için taguchi metodu kullanarak optimizasyon yapmışlardır. Kesme parametrelerini, S/N oranı ve ANOVA kullanılarak optimize etmişlerdir. Kesme parametreleri arasında yüzey pürüzlülüğünü etkileyen en önemli parametrenin ilerlemenin olduğunu bulmuşlardır [16]. Selvaraj ve Chandramohan, yaptıkları çalışmada AISI 304 östenitik paslanmaz çeliğin kuru tornalama sırasındaki yüzey pürüzlülüğünü en aza indiren en uygun kesme parametrelerini bulmak için Taguchi optimizasyon yöntemi uygulamışlardır. Kesme parametrelerinin optimizasyonu için 3 seviyeli L9 ortogonal dizilimi, S/N oranı ve ANOVA kullanmışlardır. ANOVA sonuçlarından, yüzey pürüzlülüğünü sırasıyla en çok ilerleme, kesme hızı ve kesme derinliği etkilediğini bulmuşlardır [17]. Rogov ve Siamak çalışmalarında Alüminyum Alaşımlı AA2024 tornalanmasında titreşim ve yüzey pürüzlülüğünün optimizasyonu için Taguchi metodu kullanmışlardır. Kesme hızı, ilerleme, kesme derinliği ve takım tutucu bağlama uzunluğu için 3 seviyeli $\mathrm{L}_{9}$ ortogonal dizilimi ve ANOVA uygulamışlardır. ANOVA sonuçlarından yüzey pürüzlülüğü üzerinde en önemli parametrenin kesme hızı titreşim üzerinde ise takım tutucu bağlama uzunluğunun olduğunu bulmuşlardır [18]. Munawar ve ark. Taguchi metodu kullanarak AISI 1040 çeliğinin tornalanmasında kesici takım titreşimlerinin, kesici takım burun yarıçapının ve ilerlemenin yüzey pürüzlülüğü üzerinde etkilerinin optimizasyonu yapmışlardır. Giriş parametrelerin çıkış parametresi üzerindeki etkilerini görmek için 3 seviyeli $\mathrm{L}_{9}$ ortogonal dizilimi ve ANOVA uygulamışlardır. ANOVA sonuçlarından yüzey pürüzlülüğü üzerinde sırasıyla kesici takım burun yarıçapının, titreşim genliği ve ilerlemenin önemli bir etkiye sahip olduğunu tespit etmişlerdir [19]. Kara ve ark. AISI 4140 ıslah çeliğinin tornalanmasında kesme parametrelerinin performanslarını ve optimum işleme şartlarını belirleyen bir çalışma yürütmüşlerdir. Tornalama deneyleri, Taguchi $\mathrm{L}_{16}$ ortogonal dizilimine göre yapmışlar ve deney sonuçlarının değerlendirilmesinde ise $\mathrm{S} / \mathrm{N}$ oranını esas almışlardır. Taguchi metodu kullanılarak optimum yüzey pürüzlülügü ve titreşim genliği değerlerini veren kontrol faktörlerini belirlemişlerdir. ANOVA sonuçlarına göre, yüzey pürüzlülüğü üzerindeki en etkili parametrenin ilerleme (\% 92,63), daha sonra sirasıyla kesme derinliği (\% 2,08) ve kesme hızı (\% 1,37) olduğunu bulmuşlardır. Ayrıca titreşim üzerindeki en etkili parametrelerin ise ilerleme $(\%$ 88,96), daha sonra sirasılyla kesme derinliği $(\% 6,50)$ ve kesme hızının (\% 4,54) olduğunu tespit etmişlerdir [20]. Şeremet ve Kam AISI 4140 1slah çeliğinin tornalamasında işleme parametrelerinin yüzey pürüzlülüğü ve takım aşınması ile ilgili literatürdeki çalışmaların genel bir değerlendirmesini yapmışlardır. Yaptıkları araştırmalar neticesinde literatürde uygulanan deneylerin birçoğunda kesme hızı, ilerleme ve kesme derinliği en etkili parametreler olduğunu tespit etmişledir [21]. Viswanathan ve ark. kuru ve MQL işleme şartlarında kesme parametrelerinin takım aşınması, kesme kuvvetleri, yüzey pürüzlülüğü ve kesme sıcaklığı üzerindeki etkisini belirlemek için Taguchi gri ilişkiler analizi yapmışlardır. Optimizsayon analizleri sonucunda kesme parametreleri arasında en önemli faktörün ilerleme daha sonra sırasıyla kesme derinliği ve kesme hızı olduğunu tespit etmişlerdir. Ayrıca MQL ile işlemenin kuru işlemeye göre daha iyi sonuçlar verdiğini bulmuşlardır [22]. Benzer bir çalışmada Zaman ve Dhar tarafından gerçekleştirilmiştir. Sabit kesme parametrelerinde MQL ile işleme şartlarının kesme kuvvetleri, yüzey 


\begin{tabular}{|c|c|c|}
\hline & $\begin{array}{l}\text { BŞEÜ Fen Bilimleri Dergisi } \\
6(2), 119-134,2019\end{array}$ & $\begin{array}{r}\text { BSEU Journal of Science } \\
\text { DOI: } 10.35193 / \text { bseufbd. } 622853\end{array}$ \\
\hline & & 58-7575 (http://dergipark.gov.tr/bseufbd) \\
\hline
\end{tabular}

pürüzlülüğü ve kesme sıcaklığı üzerindeki etkisini belirlemek için Taguchi gri ilişkiler analizi yapmışlardır. Optimizasyon sonuçlarına göre çift jet MQL mikro nozülün performansı kesme kuvvetleri, yüzey pürüzlülüğü ve kesme sıcaklığı açısından diğer işleme koşullarına göre en etkili olduğunu bulmuşlardır [23]. Kuntoğlu ve Sağlam farklı kesme parametrelerinde AISI 1050 çeliğinin tornalanması sonucu oluşan kesme kuvvetleri ve takım aşınmasını Taguchi metodu kullanarak analiz etmişlerdir. ANOVA sonuçlarına göre takım aşınması üzerinde en etkili parametrenin kesme hızı olduğunu, kesme kuvvetleri üzerinde ise en etkili parametrenin ilerleme olduğunu tespit etmişlerdir [24]. Das ve ark. Taguchi $\mathrm{L}_{27}$ ortogonal dizilimini yüzey pürüzlülüğü, takım aşınması ve talaş kaldırma oranının analizi için kullanmışlardır. ANOVA analizlerine göre yüzey pürüzlülüğü, takım aşınması ve talaş kaldırma oranı üzerinde en etkili parametrenin ilerleme olduğunu bulmuşlardır. Yüzey pürüzlülüğü, takım aşınması ve talaş kaldırma oranı için optimum işleme şartlarının 246,4 m/dak kesme hızı, $0,216 \mathrm{~mm} / \mathrm{dev}$ ilerleme ve $0,781 \mathrm{~mm}$ kesme derinliği olduğunu tespit etmişlerdir [25].

Bu çalışmanın amacı ideal ve optimum yüzey pürüzlülüğü ve titreşim değerleri için ayna ve punta basıncını belirlemektir. Deneylerin tasarımında ve analizinde Taguchi $\mathrm{L}_{25}$ ortogonal dizilim kullanılmıştır. Ayrıca ayna ve punta basıncının istatiksel olarak önemi S/N oranlarına göre belirlenmiştir. Son olarak, yüzey pürüzlülüğü ve titreşim üzerinde ayrı ayrı ideal ayna ve punta basıncının etkileri grafik olarak verilmiştir.

\section{II.MATERYAL VE METOT}

\section{A. İ̧s Parçası Malzemesi}

Deneylerde iş parçası malzemesi olarak çapı $35 \mathrm{~mm}$ ve boyu $300 \mathrm{~mm}$ olan AISI 304 paslanmaz çeliği kullanılmıştır. Paslanmaz çeliği grubu içinde en yaygın kullanılan AISI 304 kalite paslanmaz çelik; mekanik özelliğinin, korozyon-oksidayson direncinin, kimyasal bileşiminin, kaynak yapılabilirliğinin çok iyi olması sebebiyle tercih edilir. Deneylerde kullanılan iş parçasının kimyasal bileşimi ve sertlik değeri Tablo 1.'de verilmiştir.

Tablo 1. İş parçası malzemesinin kimyasal bileşimi ve sertlik değeri

\begin{tabular}{|c|c|c|c|c|}
\hline$\overline{\% \mathrm{C}}$ & $\% \mathrm{Mn}$ & $\% \mathrm{Si}$ & $\% \mathrm{P}$ & $\% \mathrm{~S}$ \\
\hline $0,070-0,024$ & $2,0-1,45$ & $1,00-0,39$ & $0,045-0,036$ & $0,030-0,029$ \\
\hline$\% \mathrm{Ni}$ & $\% \mathrm{~N}$ & $\% \mathrm{C0}$ & $\% \mathrm{Cr}$ & Sertlik \\
\hline $10,50-8,00$ & $0,100-0,085$ & $0,15(\max )$ & $19,50-17,50$ & $215 \mathrm{HB}$ \\
\hline
\end{tabular}

\section{B. Kesici Takımlar ve Takım Tutucu}

Deneylerde AISI 304 östenitik paslanmaz çeliğinin işlenmesi için OKE kesici takım üretici firmasının tedarikçisi olan Fidan kesici takımcıdan WNMG 080408-OMM formunda P25/M25 kalitesine sahip PVD kaplamalı karbür kesici uçlar ve bu kesici uçlara uygun olan PWLNR 2525M08 takım tutucu kullanılmıştır. Kesici uç ve takım tutucu şekli Şekil 1.’de verilmiştir.

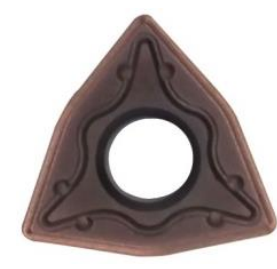

(a)

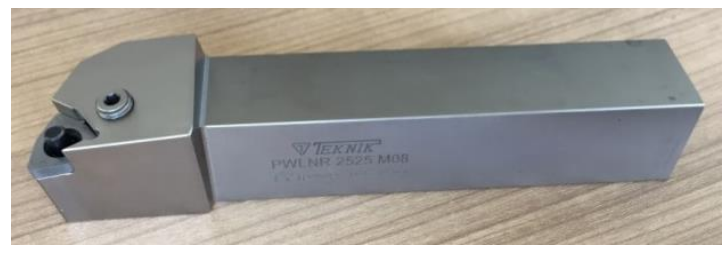

(b)

Şekil 1. (a) WNMG kesici uç, (b) PWLNR 2525M08 takım tutucu 


\section{Takım Tezgâhı ve Kesme Parametreleri}

İş parçası malzemeleri üniversal torna tezgâhında alınları tornalanıp punta delikleri açıldıktan sonra dış olumsuzlukları ortadan kaldırmak için $1 \mathrm{~mm}$ boyuna tornalama yapılıp CNC torna tezgâhında işlenmeye hazır hale getirilmiştir. İşleme deneylerinin gerçekleştirilmesinde Yavuz Kardeşler Makine imalat atölyesinde bulunan TAKİSAWA EX-310 marka CNC torna tezgâhı kullanılmıştır. Kesme parametreleri, ISO 3685 şartları ve üretici kesici takım firmasının önerileri dikkate alınarak belirlenmiştir. İşleme deneylerinde sabit kesme hızı, ilerleme ve kesme derinliğinde beş farklı ayna ve punta basıncı kullanılmıştır. İşleme deneylerinde kullanılan kesme parametreleri, ayna ve punta basıncı değerleri Tablo 2.'de verilmiştir. Grafiklerde ayna basıncı (AB) şeklinde punta basıncı ise (PB) şeklinde kısaltılarak ifade edilmiştir.

Tablo 2. İşleme deneylerinde kullanılan kesme parametreleri

\begin{tabular}{ll}
\hline Kesme Hızı, V (m/dk) & 250 \\
\hline İlerleme, f (mm/dev) & 0,2 \\
\hline Kesme derinliği, a (mm) & 2 \\
\hline Ayna Basınç, P (bar) & $10,12,14,16,18$ \\
\hline Punta Basıç, P (bar) & $5,8,11,14,17$ \\
\hline
\end{tabular}

\section{Yüzey Pürüzlülük ve Titreşim Ölçümü}

İşleme deneyleri sonucu oluşan iş parçası yüzeyindeki yüzey pürüzlülükleri taşınabilir TR 200 ölçüm cihazı kullanılarak ölçülmüşsür. Yüzey pürüzlülük değerleri, işlenmiş her bir deney numunesinin yüzeyinden 5 $\mathrm{mm}$ ölçme boyunda beş ayrı ölçümün aritmetik ortalaması alınarak hesaplanmıştır. Tornalama işlemi sırasında oluşan iş parçasındaki titreşimler NI-9230 3 boyutlu ivmeölçer ölçüm cihazı ile bilgisayar bağlantılı bir şekilde ölçülmüş ve elde edilen ölçüm değerleri grafiklere aktarılmıştır. İşleme deneyleri, deneylerde ölçülen yüzey pürüzlülük ve titreşim ölçümleri için kurulan deney düzeneği Şekil 2'de verilmiştir.

\section{DENEYSEL SONUÇLAR VE İSTATISTIKSEL ANALİZ}

$\mathrm{Bu}$ deneysel çalışmada, sabit kesme parametrelerinde silindirik tornalama işlemlerinde ayna ve punta basıncının yüzey pürüzlülüğü ve titreşim değerleri üzerindeki etkileri araştııılmıştır. İşleme deneylerinden elde edilen deneysel sonuçlar yüzey pürüzlülük ve titreşim açıssndan iki alt başlıkta değerlendirilmiştir. 


\begin{tabular}{|c|c|c|}
\hline & $\begin{array}{l}\text { BŞEÜ Fen Bilimleri Dergisi } \\
6(2), 119-134,2019\end{array}$ & $\begin{array}{r}\text { BSEU Journal of Science } \\
\text { DOI: } 10.35193 / \text { bseufbd.622853 }\end{array}$ \\
\hline ERSI & & 58-7575 (http://dergipark.gov.tr/bseufbd) \\
\hline
\end{tabular}

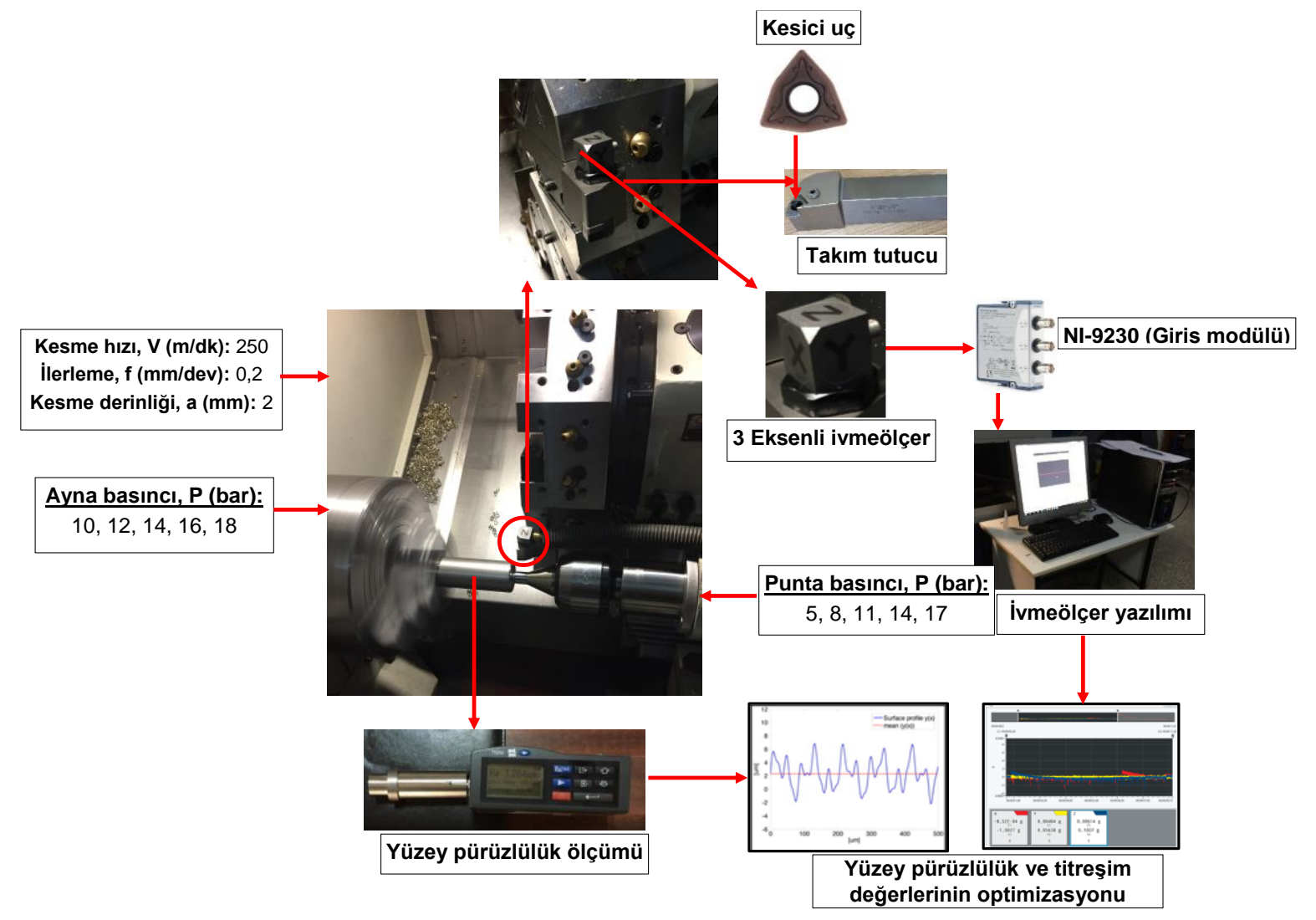

Şekil 2. Deney düzeneğinin şematik gösterimi

\section{A. Yüzey Pürüzlülüğü ve Titreşim sonuçlarının Değerlendirilmesi}

Sabit kesme parametrelerinde, beș farklı ayna ve punta basıncına bağlı olarak tornalanan iş parçalarının yüzeyinden elde edilen yüzey pürüzlülük değerleri Şekil 3 ve Şekil 4 'te verilmiştir. Şekil 3 ve Şekil 4 'teki grafikler incelendiğinde ayna ve punta basıncının yüzey pürüzlülük üzerinde önemli bir etkiye sahip olduğu tespit edilmiştir. En yüksek yüzey pürüzlülük değeri punta basıncı 14 bar ve ayna basıncı 10 barda iş parçaları işlenirken en düşük yüzey pürüzlülük değeri ise punta basıncı 5 bar ve ayna basıncı 18 barda iș parçaları işlenirken elde edildiği Şekil 3’teki grafikte görülmektedir. Yüzey pürüzlülük açısından bütün ayna basınçları için ideal punta basıncının 11 bar olduğu tespit edilmiştir. Şekil 4 'teki grafik incelendiğinde en yüksek yüzey pürüzlülük değeri ayna basıncı 10 bar ve punta basınc1 14 bar olduğunda elde edilirken en düşük yüzey pürüzlülük değeri ise ayna basıncı 18 bar ve punta basıncı 5 barda işlenen iş parçalarının yüzeyinden elde edilmiștir. Yüzey pürüzlülük açısından bütün punta basınçları için ideal ayna basıncının 18 bar olduğu tespit edilmiştir. 


\begin{tabular}{|c|c|c|}
\hline & $\begin{array}{l}\text { BŞEÜ Fen Bilimleri Dergisi } \\
6(2), 119-134,2019\end{array}$ & $\begin{array}{r}\text { BSEU Journal of Science } \\
\text { DOI: } 10.35193 / \text { bseufbd.622853 }\end{array}$ \\
\hline ERSI & & 58-7575 (http://dergipark.gov.tr/bseufbd) \\
\hline
\end{tabular}

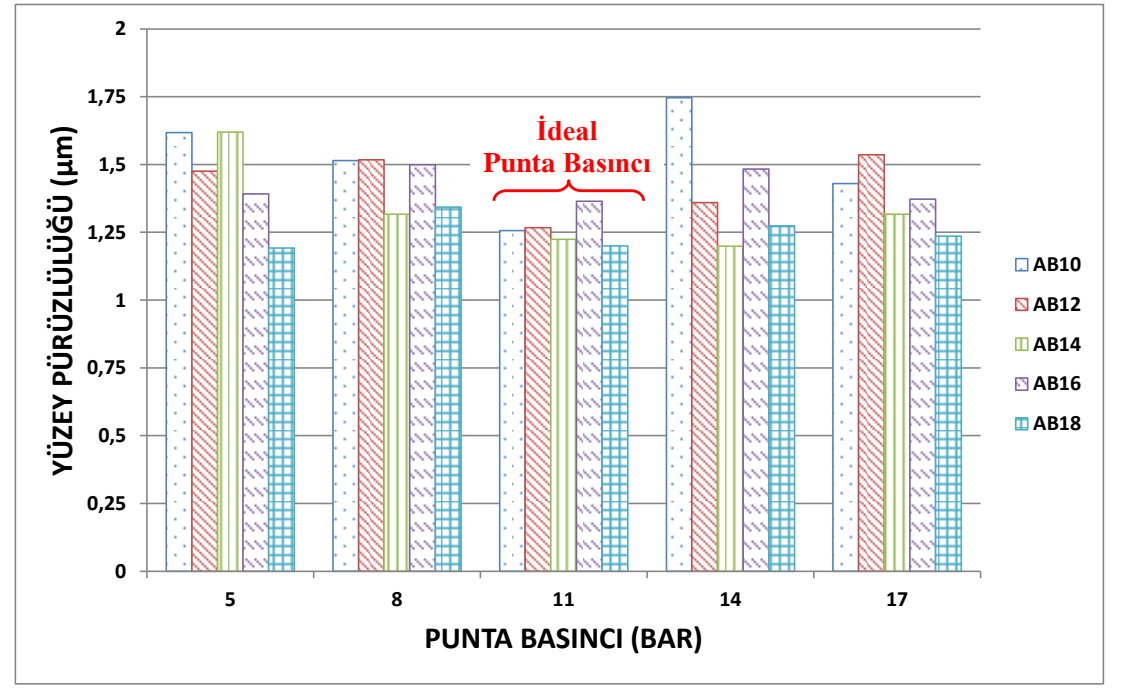

Şekil 3. AISI 304 paslanmaz çeliğinin sabit kesme parametrelerinde işlenirken punta basıncına bağlı olarak elde edilen yüzey pürüzlülük değerleri

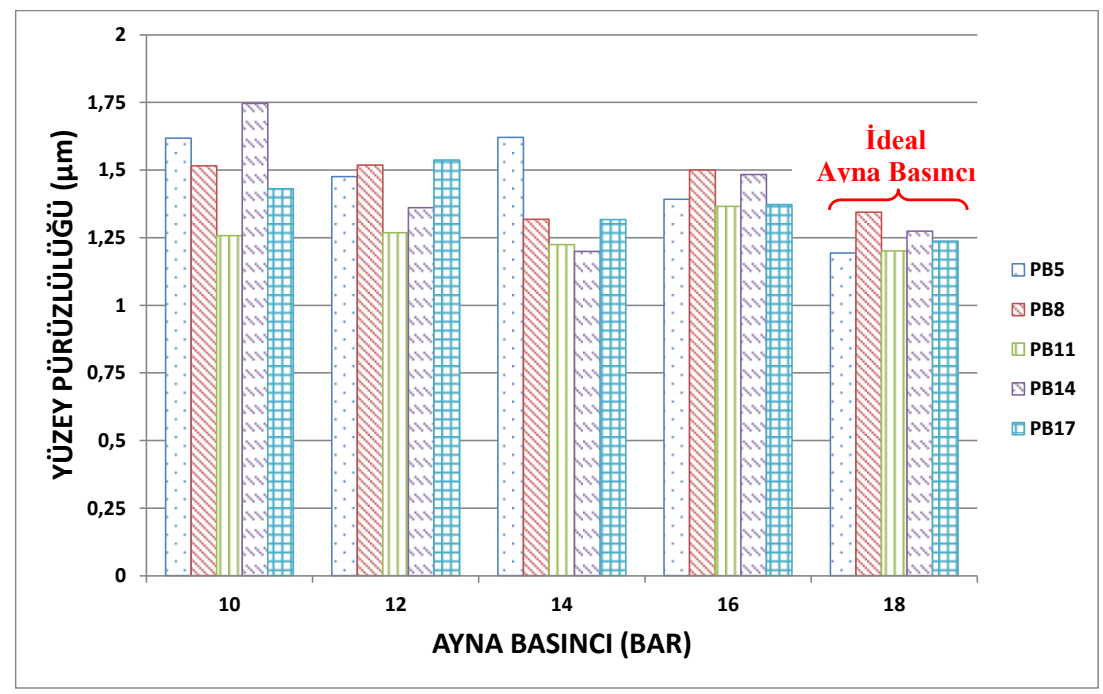

Şekil 4. AISI 304 paslanmaz çeliğinin sabit kesme parametrelerinde işlenirken ayna basıncına bağlı olarak elde edilen yüzey pürüzlülük değerleri

Ayna ve punta basıncına bağlı olarak sabit kesme parametrelerinde elde edilen titreşim değerleri Şekil 5 ve Şekil 6'da verilmiştir. Şekil 5 ve Şekil 6'daki grafikler incelendiğinde titreşim üzerinde ayna ve punta basıncının etkili olduğu görülmektedir. Şekil 6'daki grafiğe bakıldığında en yüksek titreşim değeri punta basıncı 14 bar ve ayna basınc1 10 barda olduğunda en düşük titreşim değeri ise punta basıncı 5 bar ve ayna basıncı 18 barda iş parçaları işlenirken elde edilmiştir. Titreşim açısından bütün ayna basınçları için ideal punta basıncının 11 bar olduğu tespit edilmiştir. Şekil 6'daki grafik incelendiğinde en yüksek titreşim değeri ayna basınc1 10 bar ve punta basıncı 14 bar olduğunda elde edilirken en düşük titreşim değeri ise ayna basıncı 18 bar ve punta basınc1 5 barda iş parçaları işlenirken ortaya çıktığı görülmüştür. Titreşim açısından bütün punta basınçları için ideal ayna basıncının 18 bar olduğu tespit edilmiştir. 


\begin{tabular}{|c|c|c|}
\hline & $\begin{array}{l}\text { BŞEÜ Fen Bilimleri Dergisi } \\
6(2), 119-134,2019\end{array}$ & $\begin{array}{r}\text { BSEU Journal of Science } \\
\text { DOI: } 10.35193 / \text { bseufbd.622853 }\end{array}$ \\
\hline ERSI & & 58-7575 (http://dergipark.gov.tr/bseufbd) \\
\hline
\end{tabular}

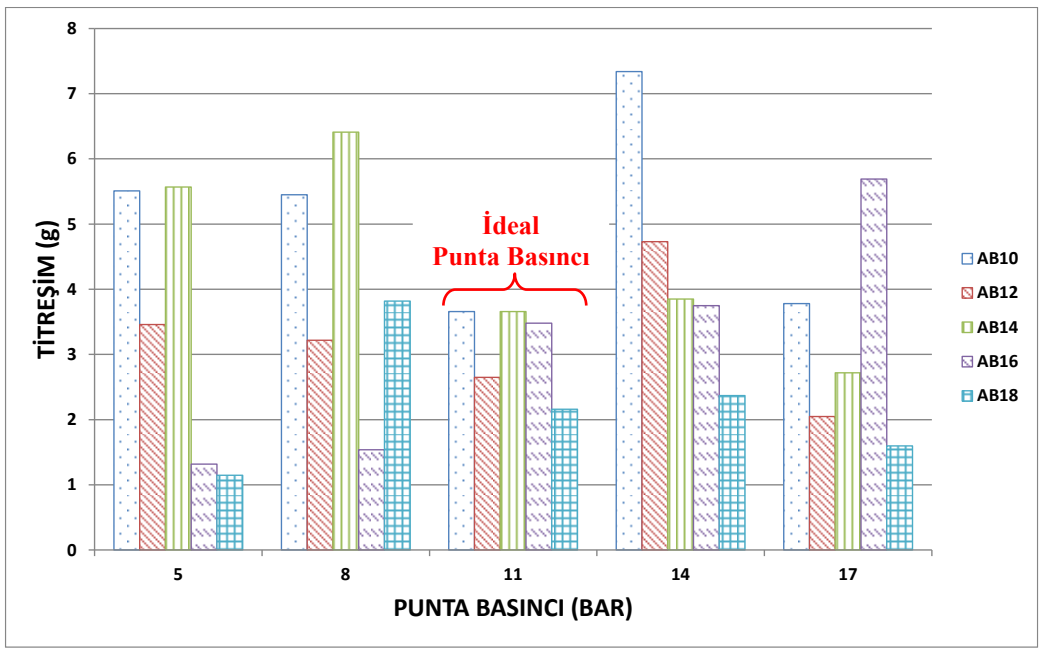

Şekil 5. AISI 304 paslanmaz çeliğinin sabit kesme parametrelerinde işlenirken punta basıncına bağlı olarak elde edilen titreşim değerleri

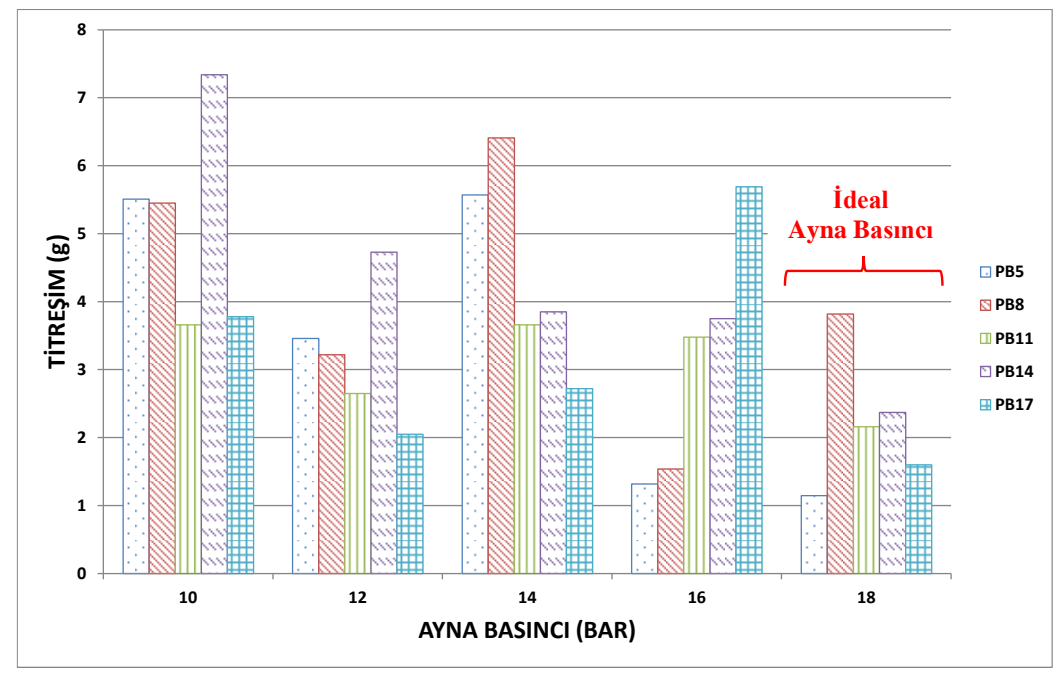

Şekil 6. AISI 304 paslanmaz çeliğinin sabit kesme parametrelerinde işlenirken ayna basıncına bağlı olarak elde edilen titreşim değerleri

\section{B. S/N Oranının Analizi}

Taguchi metodunda deneysel verilerin analizlerinde kullanılan en temel kriter $\mathrm{S} / \mathrm{N}$ oranıdır. Taguchi yönteminde "Sinyal" terimi, çıkış karakteristiği için istenen değeri (ortalama), "Gürültü" terimi ise çıkış karakteristiği için istenmeyen değeri temsil eder. $\mathrm{Bu}$ deneysel çalışmada, Taguchi $\mathrm{L}_{25}$ ortogonal dizilim metodunda en küçük en iyi yaklaşımına göre $\mathrm{S} / \mathrm{N}$ oranı denklemi kullanılmıştır. Taguchi metoduna göre en düşük yüzey pürüzlülüğü ve titreşim değerleri için gerekli olan optimum ayna ve punta basınçları $\mathrm{S} / \mathrm{N}$ oranıyla tespit edilmiştir. $\mathrm{S} / \mathrm{N}$ formülü aşağıda bulunan Eşitlik 1'de gösterilmiştir.

$$
S / N=-10 x \log \left[\left(\frac{1}{n}\right) \sum_{i=1}^{n} y_{i}^{2}\right]
$$

Burada; $y_{i}$ : değişkenin ölçülen değeri (yüzey pürüzlülüğü ve titreşim), n: deney değerlerinin sayısıdır. 


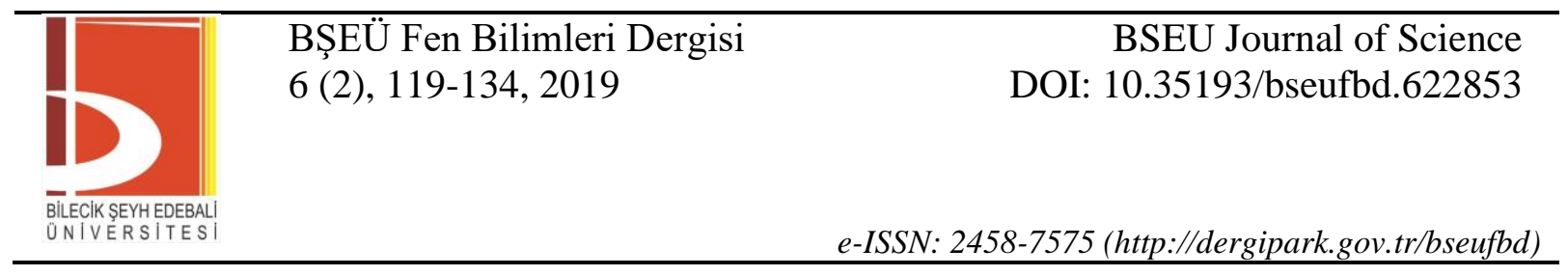

\section{Sonuçlar ve Tartışma}

Bu çalışmada, ayna ve punta basınçlarının yüzey pürüzlülüğü ve titreşim üzerine olan etkileri Taguchi $\mathrm{L}_{25}$ ortogonal dizilimi ile optimize edilmiştir. Ayrıca $\mathrm{S} / \mathrm{N}$ oranına bağlı olarak yüzey pürüzlülüğü ve titreşim üzerine ayna ve punta basıncının etkinliği araştırılmıştır. Deneysel tasarımda kullanılan ortogonal diziliminde giriş parametreleri olarak ayna ve punta basıncı iki faktör olacak şekilde alınmıştır. Her bir faktör için beşer seviye belirlenerek çıkış parametreleri olan yüzey pürüzlülüğü ve titreşim değerleri optimize edilmiştir. Deneylerde kullanılan kontrol faktörleri ve seviyeleri Tablo 3 'te verilmiştir.

Tablo 3. Kontrol Faktörler ve seviyeleri

\begin{tabular}{ccccccc}
\hline Kontrol faktörleri & \multirow{2}{*}{ Birim } & \multicolumn{5}{c}{ Seviyeler } \\
\cline { 3 - 7 } & & 1 & 2 & 3 & 4 & 5 \\
\hline Ayna Basinc1 & Bar & 10 & 12 & 14 & 16 & 18 \\
\hline Punta Basinc1 & Bar & 5 & 8 & 11 & 14 & 17 \\
\hline
\end{tabular}

Kontrol faktörleri ve seviyeleri ve bunlara ait yüzey pürüzlülüğü ve titreşim değerleri Tablo 4'te verilmiştir. Yüzey pürüzlülüğü ve titreşim değerlerini optimum yapan ayna ve punta basıncının değerleri, $\mathrm{L}_{25}$ ortogonal Taguchi metodundan elde edilen $\mathrm{S} / \mathrm{N}$ oranlarına göre hesaplanmıştır.

Tablo 4. Taguchi $\mathrm{L}_{25}$ ortogonal dizilim

\begin{tabular}{|c|c|c|c|c|}
\hline $\begin{array}{l}\text { Deney } \\
\text { No }\end{array}$ & $\begin{array}{c}\text { Ayna } \\
\text { Basıncı, } \\
\text { Bar }\end{array}$ & $\begin{array}{c}\text { Punta Basıncı, } \\
\text { Bar }\end{array}$ & $\begin{array}{c}\text { Yüzey Pürüzlülü̈ğü, } \\
\operatorname{Ra}(\mu \mathrm{m})\end{array}$ & $\begin{array}{l}\text { Titreşim } \\
\text { Genliği, g }\end{array}$ \\
\hline 1 & 10 & 5 & 1,61767 & 5,51 \\
\hline 2 & 10 & 8 & 1,51533 & 5,45 \\
\hline 3 & 10 & 11 & 1,257 & 3,66 \\
\hline 4 & 10 & 14 & 1,74633 & 7,34 \\
\hline 5 & 10 & 17 & 1,43 & 3,78 \\
\hline 6 & 12 & 5 & 1,47567 & 3,46 \\
\hline 7 & 12 & 8 & 1,51767 & 3,22 \\
\hline 8 & 12 & 11 & 1,26767 & 2,65 \\
\hline 9 & 12 & 14 & 1,36 & 4,73 \\
\hline 10 & 12 & 17 & 1,53633 & 2,05 \\
\hline 11 & 14 & 5 & 1,62033 & 5,57 \\
\hline 12 & 14 & 8 & 1,31733 & 6,41 \\
\hline 13 & 14 & 11 & 1,22433 & 3,66 \\
\hline 14 & 14 & 14 & 1,199 & 3,85 \\
\hline 15 & 14 & 17 & 1,31667 & 2,72 \\
\hline 16 & 16 & 5 & 1,39167 & 1,32 \\
\hline 17 & 16 & 8 & 1,49967 & 1,54 \\
\hline 18 & 16 & 11 & 1,365 & 3,48 \\
\hline 19 & 16 & 14 & 1,48333 & 3,75 \\
\hline 20 & 16 & 17 & 1,37233 & 5,69 \\
\hline 21 & 18 & 5 & 1,19267 & 1,148 \\
\hline 22 & 18 & 8 & 1,34367 & 3,82 \\
\hline 23 & 18 & 11 & 1,20067 & 2,16 \\
\hline 24 & 18 & 14 & 1,274 & 2,37 \\
\hline 25 & 18 & 17 & 1,23667 & 1,6 \\
\hline
\end{tabular}




\begin{tabular}{|c|c|c|}
\hline & $\begin{array}{l}\text { BŞEÜ Fen Bilimleri Dergisi } \\
6(2), 119-134,2019\end{array}$ & $\begin{array}{r}\text { BSEU Journal of Science } \\
\text { DOI: } 10.35193 / \text { bseufbd. } 622853\end{array}$ \\
\hline & & 58-7575 (http://dergipark.gov.tr/bseufbd) \\
\hline
\end{tabular}

Ayna ve punta basıncının yüzey pürüzlülüğü ve titreşim değerleri üzerindeki etkilerini gösteren $\mathrm{S} / \mathrm{N}$ oranlarının grafikleri Şekil 7 - Şekil 8'de verilmiştir.

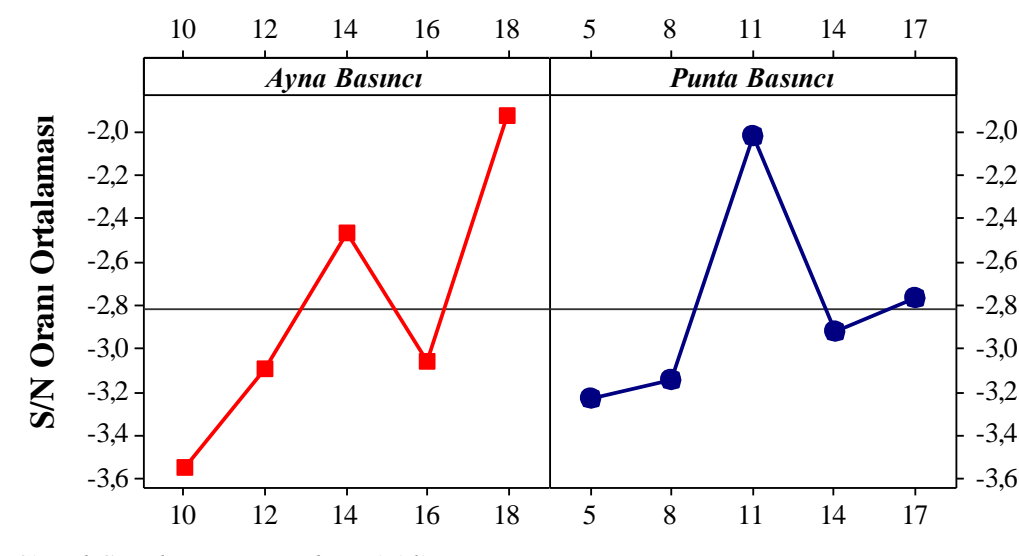

Sinyal Gürültü : En Küçük En iyidir

Şekil 7. Yüzey pürüzlülüğü için S/N oranının ana etki grafiği

Şekil 7'deki grafik incelendiğinde $\mathrm{S} / \mathrm{N}$ oranlarının en büyük ortalamasına göre optimum yüzey pürüzlülüğü değerlerini veren ayna basınc1 18 bar ve punta basınc1 11 bar olduğu görülmektedir. Diğer bir ifadeyle ayna basıncı için beşinci seviye, punta basıncı için ise üçüncü seviyedeki $\mathrm{S} / \mathrm{N}$ değerleri optimum yüzey pürüzlülük değerini vermektedir.

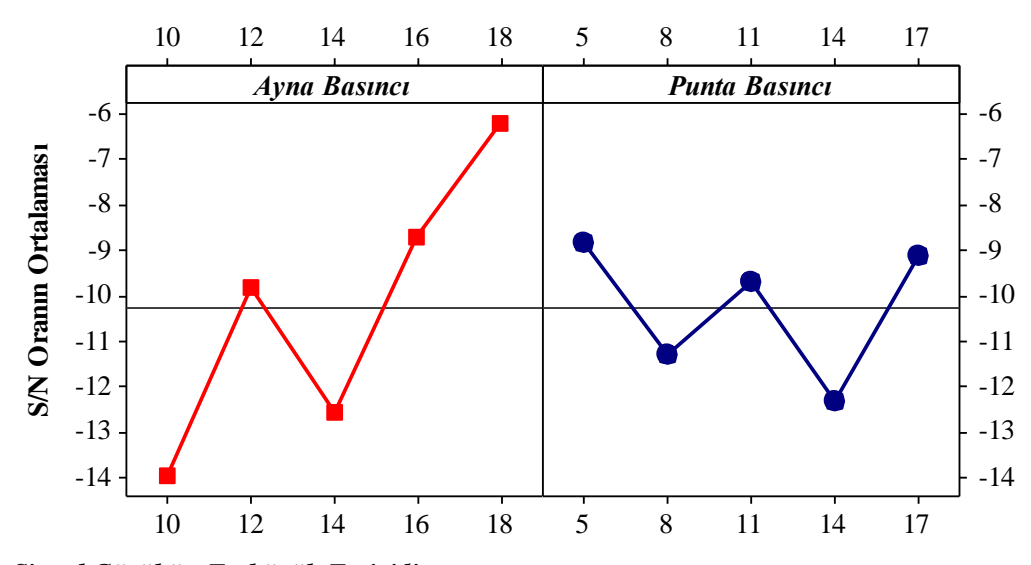

Sinyal Gürültü : En küçük En iyidir

Şekil 8. Titreşim için $\mathrm{S} / \mathrm{N}$ oranı ana etki grafiği

Şekil 8'deki titreşim değerlerini veren $\mathrm{S} / \mathrm{N}$ grafikleri incelendiğinde ayna basıncı 18 bar ve punta basınc 5 bar olduğu değerlerde optimum titreşim değerlerini verdiği görülmektedir. $\mathrm{L}_{25}$ ortogonal dizilimine göre hesaplanan $\mathrm{S} / \mathrm{N}$ oranları değerleri Tablo 5.’te verilmiştir. Tablo 5.'teki $\mathrm{S} / \mathrm{N}$ oranlarına göre optimum yüzey pürüzlülüğünü veren değerler ayna basıncı beşinci seviye, punta basıncı üçüncü seviye iken optimum titreşimi veren değerler ise ayna basıncı beşinci seviye, punta basıncı birinci seviye olduğu görülmektedir. Yüzey pürüzlülüğü ve titreşim değerleri için elde edilen $\mathrm{S} / \mathrm{N}$ oranlarını veren Tablo 5 'teki değerler incelendiğinde sıralama ve delta değerlerine göre ayna basıncının punta basıncından daha etkili olduğu anlaşılmaktadır. Etki parametresinin bir diğer göstergesi olan delta değerinin büyük olması parametrenin etkinliğinin daha fazla 
olduğunu göstermektedir. Sonuç olarak $\mathrm{S} / \mathrm{N}$ oranlarına göre yüzey pürüzlülüğü ve titreşim üzerinde ayna basıncının punta basıncına göre daha önemli ve etkili olduğu tespit edilmiştir.

Tablo 5. En küçük en iyidir için $\mathrm{S} / \mathrm{N}$ oranları değerleri

\begin{tabular}{|c|c|c|c|c|}
\hline \multirow{3}{*}{ Seviyeler } & \multicolumn{4}{|c|}{ Kontrol Faktörleri } \\
\hline & \multicolumn{2}{|c|}{ Yüzey Pürüzlülüğg̈ü } & \multicolumn{2}{|c|}{ Titreșim } \\
\hline & Ayna Basıncı & Punta Basıncı & Ayna Basıncı & Punta Basıncı \\
\hline 1 & $-3,545$ & $-3,230$ & $-13,937$ & $-8,826$ \\
\hline 2 & $-3,093$ & $-3,143$ & $-9,827$ & $-11,283$ \\
\hline 3 & $-2,462$ & $-2,019$ & $-12,545$ & $-9,705$ \\
\hline 4 & $-3,053$ & $-2,924$ & $-8,715$ & $-12,299$ \\
\hline 5 & $-1,927$ & $-2,764$ & $-6,221$ & $-9,132$ \\
\hline Delta & 1,618 & 1,211 & 7,716 & 3,473 \\
\hline Siralama & 1 & 2 & 1 & 2 \\
\hline
\end{tabular}
verilmiştir.

Ayna basıncına göre yüzey pürüzlülüğü değerlerinin dağılımını gösteren regresyon grafiği Şekil 9'da

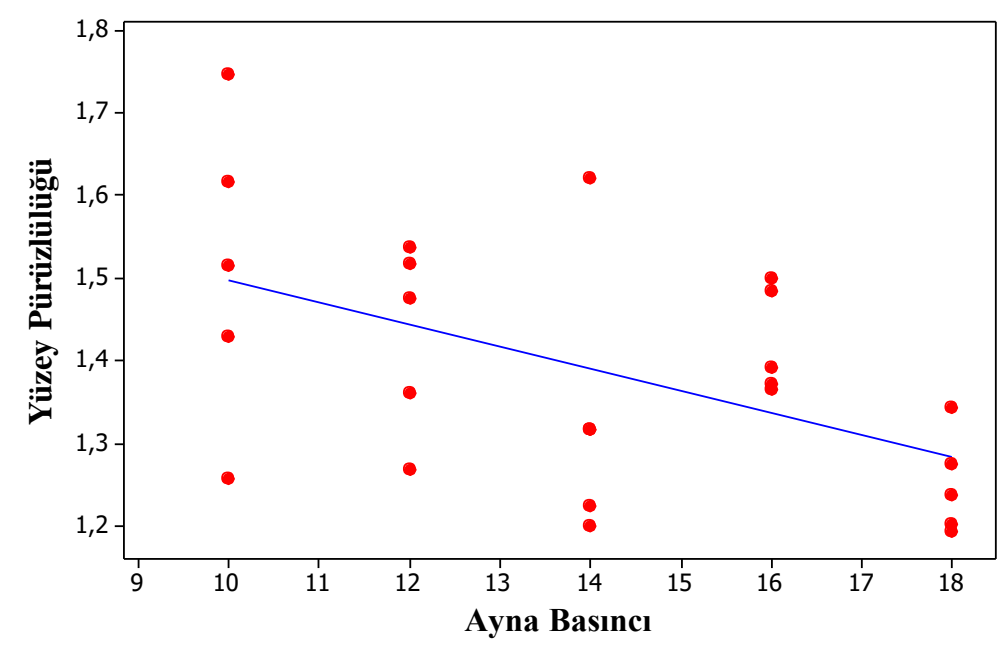

Şekil 9. Ayna basıncına göre yüzey pürüzlülük değerlerinin dağılımı

Regresyon grafiklerinde en iyi değer, lineer çizgi etrafında en yakın bir şekilde toplanan artıklardan tespit edildiği bilinmektedir. Bu yüzden Şekil 9'daki grafik incelendiğinde ayna basıncına göre optimum yüzey pürüzlülüğünü veren değerin 18 bar olduğu tespit edilmiştir. Punta basıncına bağlı olarak elde edilen yüzey pürüzlülüğü değerleri dağılımını veren regresyon grafiği Şekil 10'da verilmiştir. Şekil 10'daki regresyon grafiği incelendiğinde yüzey pürüzlülüğü için en ideal punta basıncının 11 bar olduğu görülmektedir. 


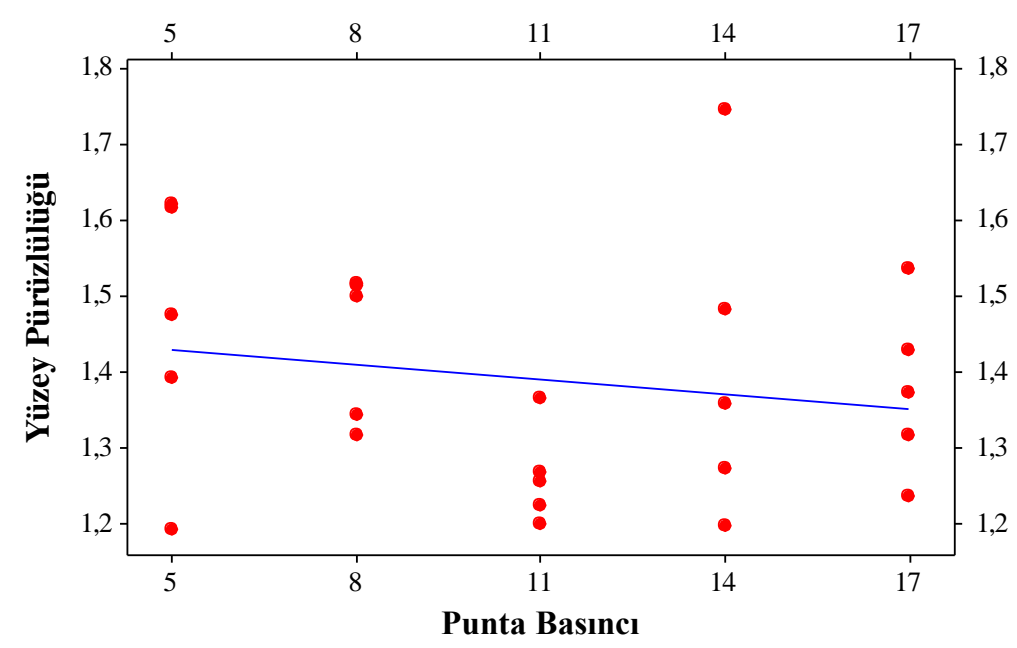

Şekil 10. Punta basıncına göre yüzey pürüzlülük değerlerinin dağılımı

Ayna ve punta basıncına bağlı olarak elde edilen titreşim değerlerinin regresyon dağılımını gösteren grafikler Şekil 11 - Şekil 12'de verilmiştir. Şekil 11'deki grafik incelendiğinde regresyon değişimlerine göre ayna basıncına bağlı olarak elde edilen titreşim değerleri için ideal ayna basıncının 18 bar olduğu görülmektedir. Punta basıncının değişimine bağlı olarak elde edilen titreşim değerlerini veren Şekil 12'deki regresyon dağılımları grafiği incelendiğinde ideal punta basıncının 11 bar olduğu tespit edilmiştir.

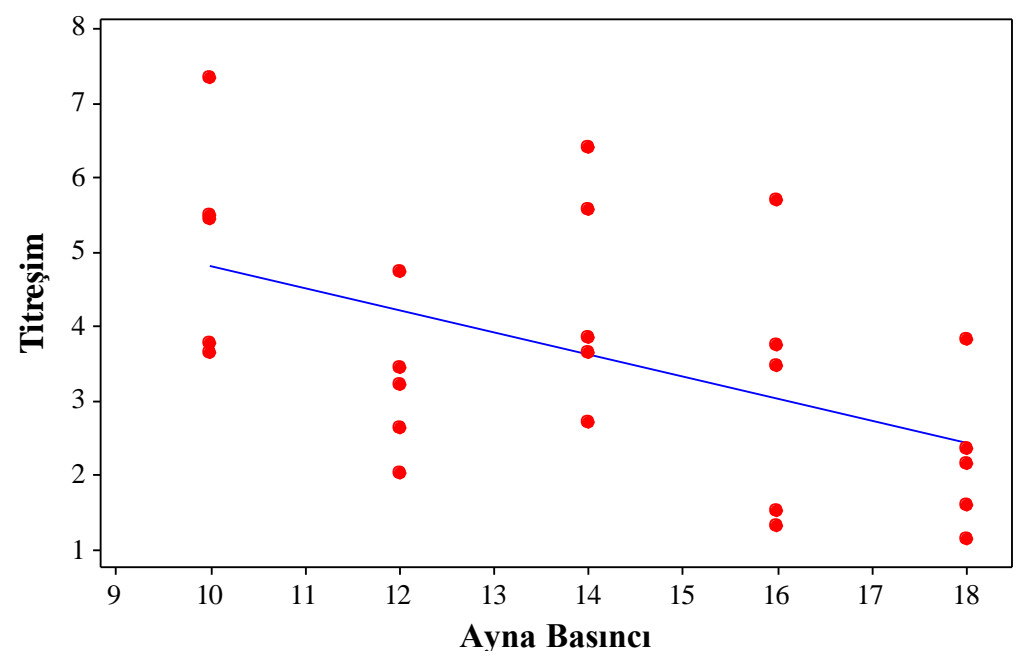

Şekil 11. Ayna basıncına göre titreşim değerlerinin dağılımı 


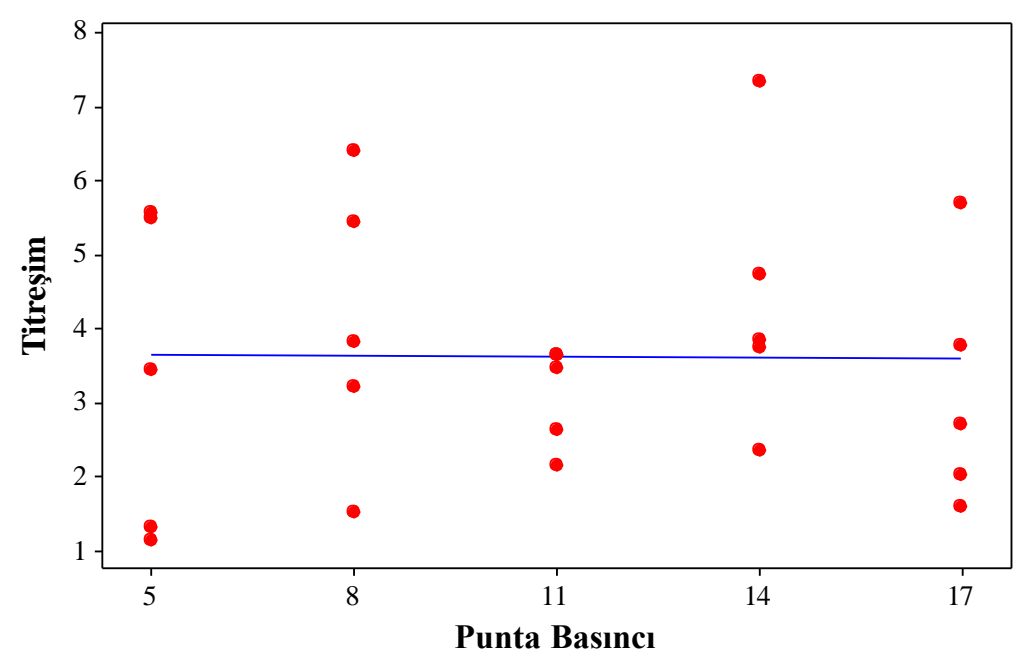

Şekil 12. Ayna basıncına göre titreşim değerlerinin dağılımı

\section{SONUÇLAR}

Bu çalışmada AISI 304 çeliğinin tornalanması sonucu oluşan titreşim ve yüzey pürüzlülüğü üzerinde ayna ve punta basınçlarının etkilerini değerlendirmek ve en uygun değişken seviyelerini bulmak için $\mathrm{S} / \mathrm{N}$ oranı ve Taguchi $\mathrm{L}_{25}$ ortogonal dizilim yöntemleri uygulanmıştır. Gerçekleştirilen deneysel ve istatiksel çalışmadan elde edilen sonuçlar aşağıda verilmiş̧tir.

Optimum yüzey pürüzlülük değerleri için ayna basınc 18 bar ve punta basıncı 11 bar iken en düşük yüzey pürüzlülük değeri içinse ayna basıncı 18 bar ve punta basıncı 5 barda iken elde edilmiştir.

Hem en düşük titreşim değeri hem de optimum titreşim değerleri için ayna basıncı 18 bar ve punta basınc1 5 bar olduğu tespit edilmiştir.

Taguchi deney tasarımı S/N oranı sonuçlarına göre yüzey pürüzlülüğü ve titreşim üzerinde ayna basıncının punta basıncından daha etkin bir parametre olduğu ortaya çıkmıştır.

Regresyon analizi grafiğindeki artık değerlere göre yüzey pürüzlülüğü değerleri üzerinde ideal ayna basınc1 18 bar, punta basınc1 11 bar olarak titreşim değerleri üzerinde ise ideal ayna basıncı 18 bar, punta basıncı 5 bar olduğu belirlenmiş̧tir.

Elde edilen sonuçlar, Taguchi metodunun başarılı bir şekilde talaşlı imalat araştırmalarında uygulanabilecek deney tasarımı ve analizi olduğunu bir kez daha göstermiştir.

\section{TEŞEKKÜR}

Yazarlar, bu çalışmanın gerçekleştirilmesinde her türlü katkı ve desteklerini sağlayan TÜBİTAK'a (Destekleme programı: 2209/B sanayi odaklı) ve Batman organize sanayisinde bulunan Yavuz Kardeşler Makineye teşekkür eder.

\section{KAYNAKLAR}

[1] Nas, E., Samtaş, G., \& Demir, H. (2012). CNC Frezelemede Yüzey Pürüzlülüğüne Etki Eden Parametrelerin Matematiksel Olarak Modellenmesi. Pamukkale Üniversitesi Mühendislik Bilimleri Dergisi, 18(1), 47-59. 
[2] Neşeli S., \& Yaldız S. (2007). Tornalamada Yaklaşma Açısı ve Talaş Açısına Bağlı Tırlama Titreşimlerinin Yüzey Pürüzlülüğüne Etkileri. Politeknik Dergisi, 10(4), 383-389.

[3] Günay, M., \& Yücel, E. (2013). Application of Taguchi method for determining optimum surface roughness in turning of high-alloy white cast iron. Measurement, 46(2), 913-919.

[4] Rao, C. M., Venkatasubbaiah, K., Babu, S. P., \& Srinivas, C. (2016). Optimization of surface roughness in CNC turning using Taguchi method and ANOVA. International Journal, 93, 1-14.

[5] Salvi, S. B., Deshmukh, R. R., \& Deshmukh, S. D. (2013). Analysis of surface roughness in hard turning by using Taguchi method. International Journal of Engineering Science and Technology, 5(02), 365-370.

[6] Debnath, S., Reddy, M. M., \& Yi, Q. S. (2016). Influence of cutting fluid conditions and cutting parameters on surface roughness and tool wear in turning process using Taguchi method. Measurement, 78, 111-119.

[7] Nalbant, M., Gökkaya, H., \& Sur, G. (2007). Application of Taguchi method in the optimization of cutting parameters for surface roughness in turning. Materials \& design, 28(4), 1379-1385.

[8] Cetin, M. H., Ozcelik, B., Kuram, E., \& Demirbas, E. (2011). Evaluation of vegetable based cutting fluids with extreme pressure and cutting parameters in turning of AISI 304L by Taguchi method. Journal of Cleaner Production, 19(17-18), 2049-2056.

[9] Bagaber, S. A., \& Yusoff, A. R. (2017). Multi-objective optimization of cutting parameters to minimize power consumption in dry turning of stainless steel 316. Journal of cleaner production, 157, 30-46.

[10] Bhattacharya, A., Das, S., Majumder, P., \& Batish, A. (2009). Estimating the effect of cutting parameters on surface finish and power consumption during high speed machining of AISI 1045 steel using Taguchi design and ANOVA. Production Engineering, 3(1), 31-40.

[11] Camposeco-Negrete, C. (2013). Optimization of cutting parameters for minimizing energy consumption in turning of AISI 6061 T6 using Taguchi methodology and ANOVA. Journal of Cleaner Production, 53, 195-203.

[12] Yaka, H., Akkuş, H., \& Uğur, L. (2016). AISI 1040 Çeliğininin Tornalamasında Kesme Parametrelerinin Yüzey Pürüzlülüğ̈̈ne Etkisinin Taguchi Metodu İle Optimizasyonu. Celal Bayar Üniversitesi Fen Bilimleri Dergisi, 12(2), 283-288.

[13] Akkuş, H. (2019). Experimental and Statistical Investigation of Surface Roughness in Turning of AISI 4140 Steel. Sakarya University Journal of Science, 23(5), 775-781.

[14] Yılmaz, B., Karabulut, Ş., \& Güllü, A. (2018). Performance analysis of new external chip breaker for efficient machining of Inconel 718 and optimization of the cutting parameters. Journal of Manufacturing Processes, 32, 553-563.

[15] Asiltürk, I., \& Akkuş, H. (2011). Determining the effect of cutting parameters on surface roughness in hard turning using the Taguchi method. Measurement, 44(9), 1697-1704.

[16] Selvaraj, D. P., Chandramohan, P., \& Mohanraj, M. (2014). Optimization of surface roughness, cutting force and tool wear of nitrogen alloyed duplex stainless steel in a dry turning process using Taguchi method. Measurement, 49, 205-215.

[17] Selvaraj, D. P., \& Chandramohan, P. (2010). Optimization of surface roughness of AISI 304 austenitic stainless steel in dry turning operation using Taguchi design method. Journal of engineering science and technology, 5(3), 293-301. 
[18] Rogov, V. A., \& Siamak, G. (2013). Optimization of surface roughness and vibration in turning of aluminum alloy AA2024 using taguchi technique. International Journal of Mechanical and Mechatronics Engineering, 7(11), 2330-2339.

[19] Munawar, M., Mufti, N. A., \& Iqbal, H. (2009). Optimization of surface finish in turning operation by considering the machine tool vibration using Taguchi method. Mehran University Research Journal of Engineering and Technology, 31, 51-58.

[20] Kara, F., Özbek, O., Kam, M., \& Saruhan, H. (2017). Optimization by Taguchi method of surface roughness and vibration in turning of AISI 4140 steel. In II. International Academic Research Congress-(INES 2017). Antalya, 1132-1140.

[21] Şeremet, M., \& Kam, M. (2019). AISI 4140 1slah çeliğinin tornalama işleminde parametrelerin yüzey pürüzlülüğü ve takım aşınmasına etkisi üzerine bir değerlendirme”, Uluslararası Marmara Fen ve Sosyal Bilimler Kongresi. 3-5 Kasım, Kocaeli, 2202-2209.

[22] Viswanathan, R., Ramesh, S., \& Subburam, V. (2018). Measurement and optimization of performance characteristics in turning of Mg alloy under dry and MQL conditions. Measurement, 120, 107-113.

[23] Zaman, P. B., \& Dhar, N. R. (2019). Design and evaluation of an embedded double jet nozzle for MQL delivery intending machinability improvement in turning operation. Journal of Manufacturing Processes, 44, 179-196.

[24] Kuntoğlu, M., \& Sağlam, H. (2019). Investigation of progressive tool wear for determining of optimized machining parameters in turning. Measurement, 140, 427-436.

[25] Das, A., Patel, S. K., Hotta, T. K., \& Biswal, B. B. (2019). Statistical analysis of different machining characteristics of EN-24 alloy steel during dry hard turning with multilayer coated cermet inserts. Measurement, 134, 123-141. 